DOI 10.32370/IA_2020_01_9

\title{
Forensic Examination of Packaging with Indications of Counterfeiting Present on Optical Media in Civil and Criminal Proceedings
}

Kofanov Andrii

Legal Advisor to the Council of Europe Programme "Decentralization and Territorial Consolidation in Ukraine”, PhD of Juridical Sciences, Associate

Professor, Professor of Department of Forensic Support and Forensic Expertise of the National Academy of Internal Affairs, Kiev, Ukraine ORCID ID 0000-0002-5242-2518 kofanov_andrey@ukr.net

\section{Pavlovska Nataliia}

PhD of Juridical Sciences, Associate Professor, Professor of Department of Civil Law and Process of the National Academy of Internal Affairs, Kiev, Ukraine ORCID ID 0000-0003-3311-0364_wwwpav@gmail.com

\section{Svoboda Eugenia}

PhD of Juridical Sciences, Associate Professor, Professor of Department of Forensic Support and Forensic Expertise of the National Academy of Internal Affairs, Kiev, Ukraine ORCID ID 0000-0002-8639-8333 jeechka@ukr.net

\section{Tereshchenko Yuliia}

PhD of Juridical Sciences, Professor of Criminal Law Disciplines and Operative and Investigative Activities of the Precarpathian Department of the

National Academy of Internal Affairs, Kyiv, Ukraine ORCID ID 0000-0002-5353-0887 vladysikter@ukr.net

\section{Strilets Halyna}

PhD of Judicial Sciences, Associate Professor of the Departament of Law of Prydunai Branch of Private Jointstock Company «Higher Educational Institution of Interregional Academy of Personnel Management», Izmail, Ukraine

ORCID ID 0000-0002-1067-0820 galinastrelets2018@ gmail.com

\section{Abstract}

Today, forensic examination of audiovisual products distributed on optical media requires extensive use of the concepts and principles of copyright and related rights, technologies of media (incl. audio and video 
cassettes, CDs) manufacture, modern cyber techniques and devices, basic principles of the forensic identification, diagnostics and situology theories.

Keywords: expertise of copyright objects and related rights, articles, computer programs and databases, implementation of phonograms, videos, programs of loans organizations.

Introduction For forensic examination, audiovisual products represent a complicated subject. During their analysis, special knowledge from the following forensic branches is applied, depending on the problem to be addressed:

- examination of intellectual property items (to identify and decrypt notation on discs and/or cassettes, which describes holders of rights to the works, as well as the information that evidences the transfer of copyright and/or related rights; to identify the work and/or advertising unit; to identify features of counterfeit products);

- trace evidence examination (to determine the methods used in manufacturing audioand videocassettes or CDs and their packaging; to identify equipment used in the manufacture of these items, etc.);

- phonoscopy (to investigate physical parameters of an audio or video recording, identify indications of editing, identify a person by his/her voice, identify the recording equipment, etc.);

- technical analysis of documents (to study the process and quality of marking made on the surface of a disk, cassette and/or their packaging, printing materials, methods of manufacturing the Ukrainian control stamp; to identify actors in video recordings, etc.);

- technical computer analysis (to search for and identify video and audio recordings on a $\mathrm{CD}$ and in the computer's memory, to determine the type of the equipment used in replicating the work, etc.);

- chemical and/or biological examination (to study materials from which audio or videocassettes, CDs, their packaging, inserts, Ukrainian control stamps, etc., were manufactured).

Counterfeit audiovisual products have tangible features that distinguish them from the licensed ones. These features are identified through expert analysis. Their presence mostly evidences the non-compliance of a specific copy of an audiovisual product comprising a disc, packaging, layout design, control stamp, etc., with the manufacturing technology and retail trade rules that are established for a similar licenced sample copy [1]. 
As a result of rapid advances in technology and changes in the legal regulation of the manufacture and distribution of phonographic and audiovisual products, changes occur in their features; thus, a standard specimen of a sample copy used for comparison purposes also changes over time. Therefore, using a standard specimen of a licenced item is only feasible when the researcher is aware of the current state of science and technology in the field of phonographic and audiovisual products.

Upon integration of expert practice, standard specimens of licenced and counterfeit sample copies of audio products were created, having specific sets of features.

Thus, when examining external packaging of a sample phonogram copy, which may be in the form of a transparent colourless polymer film and a hard plastic or cardboard case, attention should be paid to the following signs of counterfeiting: no individual shrinkwrapping; plastic self-adhesive bags that may be re-sealed; no polymer case, or injection moulding defects of polymer case in the form of air pockets or flow lines; traces of cutting tools (scissors, etc.) on the edges of liner notes or tray card; chipping of, and small cracks around the holes, etc [2].

The layout design of discs and inlays is examined to detect the presence of the following signs: poor layout design of discs and inlays (blurred images, ghosting, distorted colour rendition of images, moiré, dots instead of uniform tint, grey scale imbalance, etc.); low-quality paper used; black and white print or no accompanying illustrated booklet; unintelligible printed (especially small) text; use of fonts other than those in licenced sample copies; grammar and spelling errors; information (usually on a label side) that the examined disc is a recordable disk; no Ukrainian control stamp, unless otherwise provided by Article 8.5 of the Law of Ukraine "On Distribution of Copies of Audiovisual Works, Phonograms, Videograms, Computer Software, Databases"; an entirely new layout design of the inlay, based on different or on somewhat modified segments (where a sample copy of the legitimate product is available); inlays printed on one side only; irregular inlay edges and folding; no copyright or related rights protection signs on the inlay or information about the phonogram author(s), manufacturer, transfer of copyright and related rights to third parties; about rightsholders within Ukraine; track titles and description; the manufacturer's addresses and/or telephone numbers for filing complaints; no information about songwriters, performers, designers, photographers, etc.; no distributor logo; no tracklist indicating duration of tracks; no album 
lyrics; no album number from the copyright holder's catalogue; no manufacturer's barcode [3].

The inlay contains false information about rightsholders, such as Meccophone 200; Navigator; Neformal LLC; Studio Retro; TUDA Records; 21 st Century G.V.D. Rus; Balalayka Records; Classic Records; Gold Records; HIGH END Records; Monsters Of Rock; Pop SHOW; Pull Dance; R-Proekt; Russian Dance Studio; Star Records; Tornado Records; Ultra Studio.

- the inlay contains information about pirate trademarks (Fig. 1) [6,7,8]:

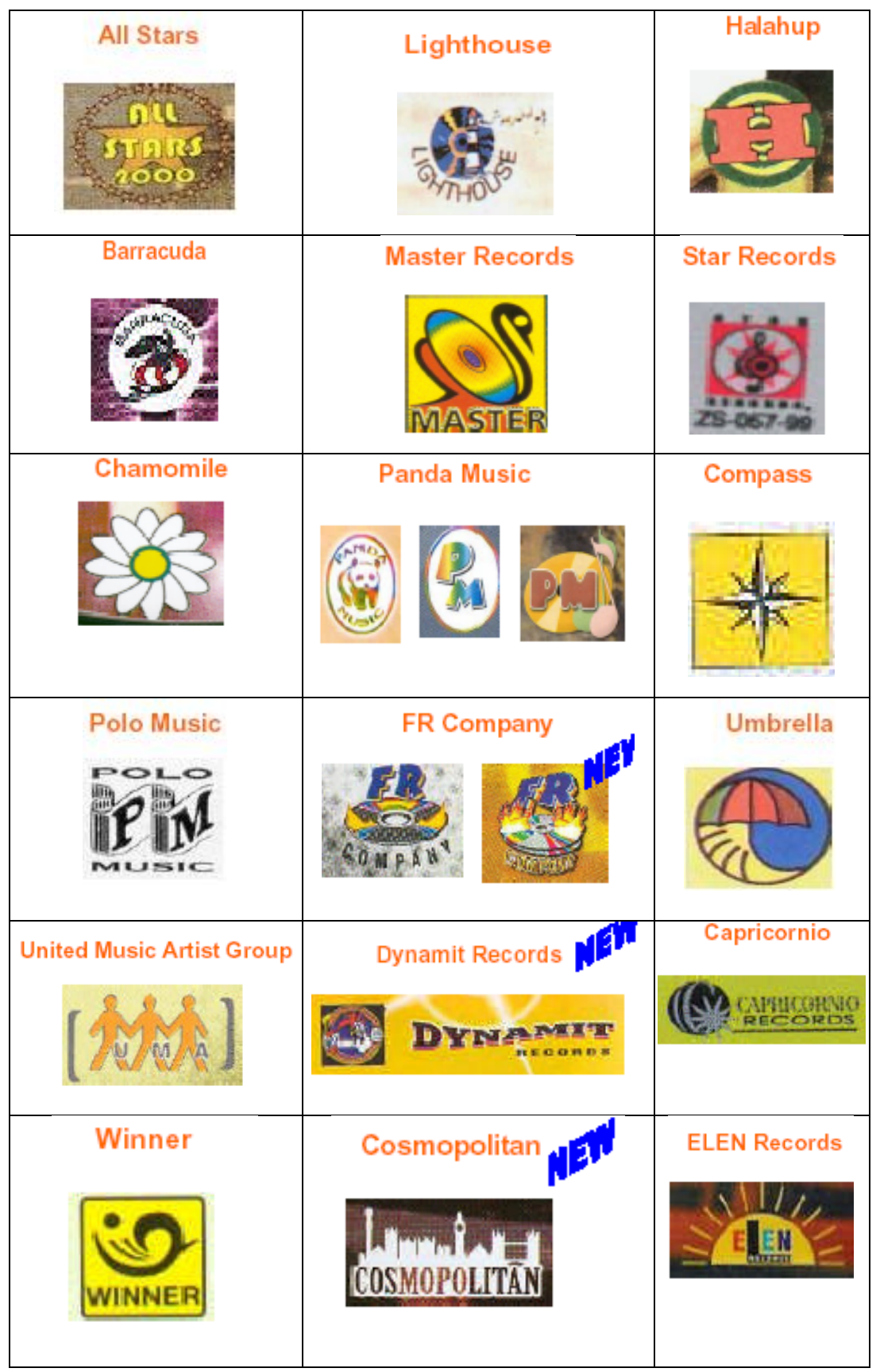




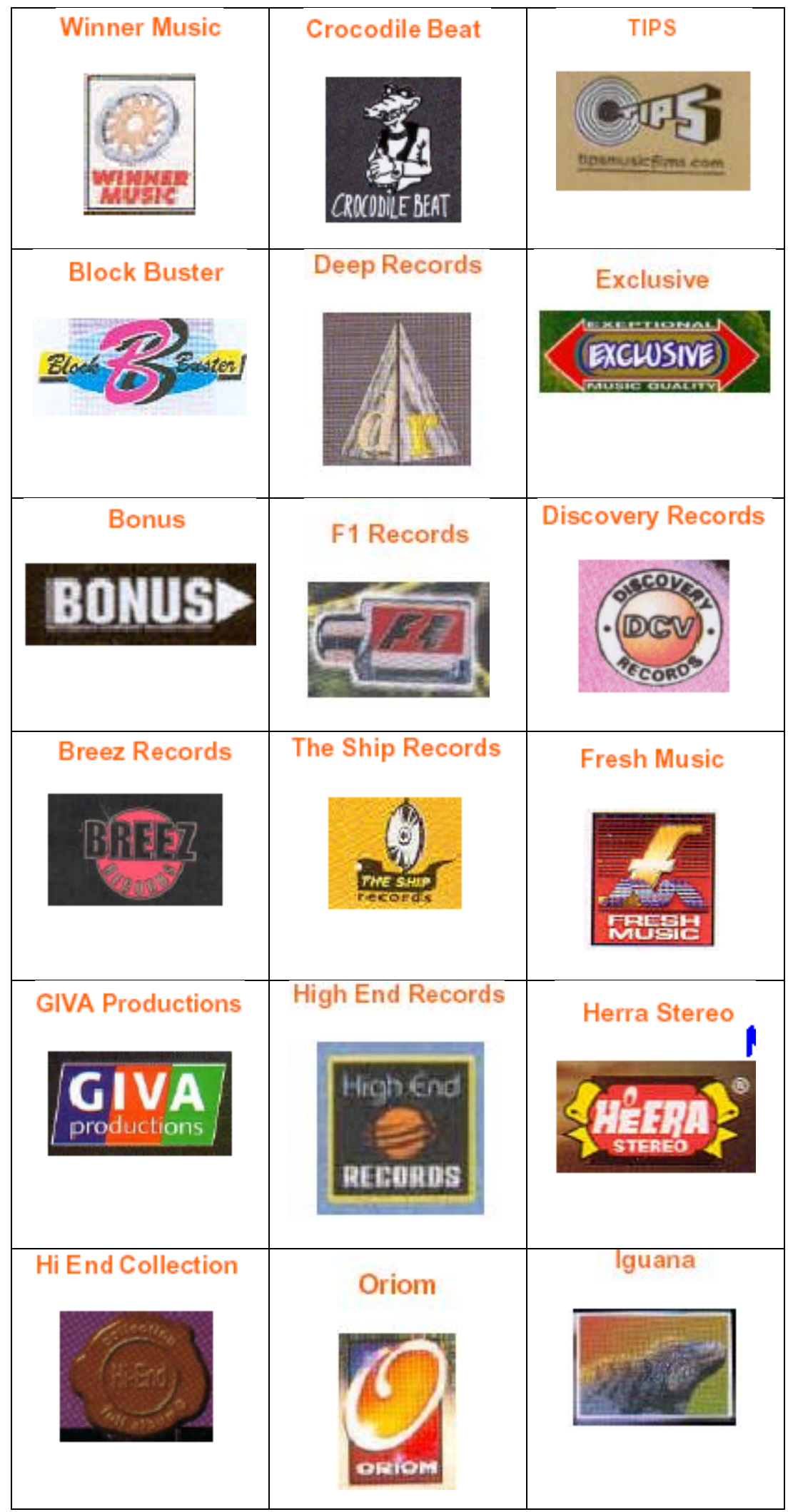




[S Records

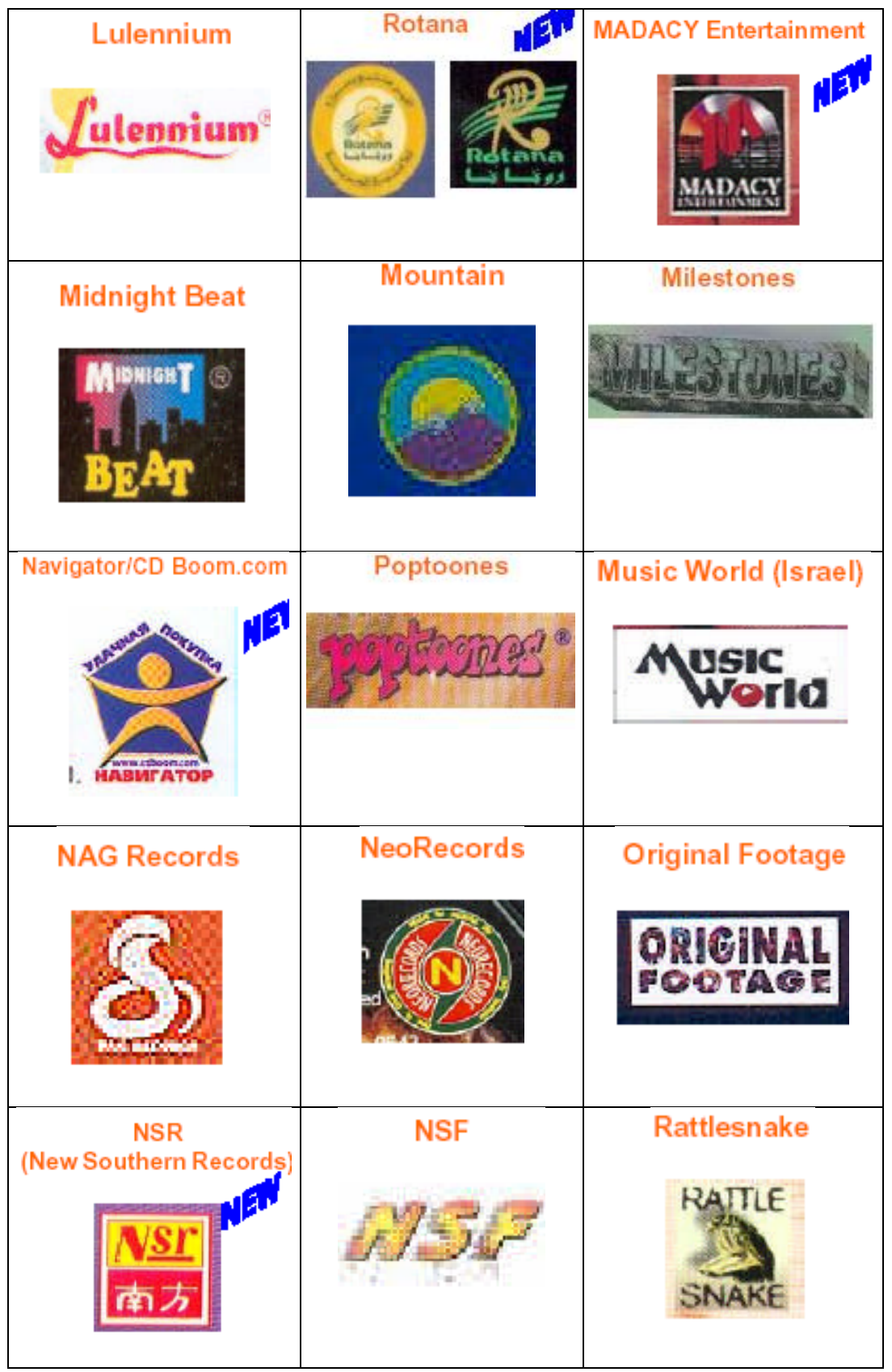




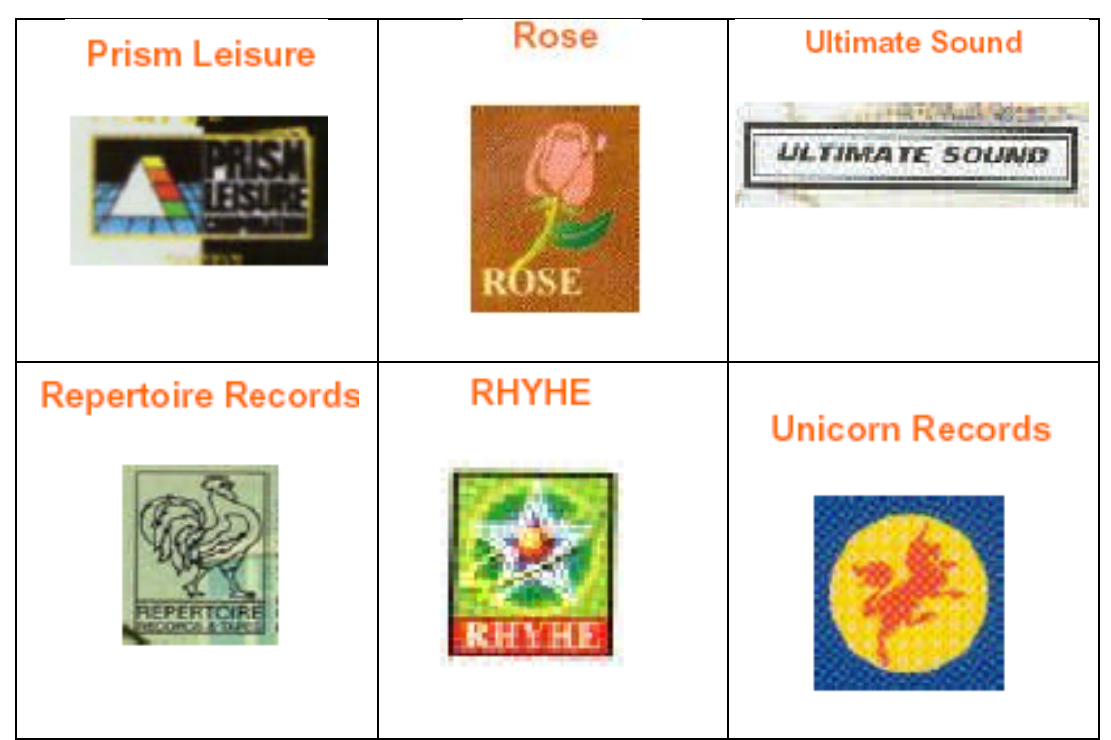

At the next stage, the storage medium - the optical disk, i.e., its label and data surfaces - is examined.

The label side of legitimate CDs contains high-quality colour images and may include information about the performer(s); track titles and description; copyright/related rights signs; first published date; information about rightsholders; rightsholder companies' logos; information about rightsholders within Ukraine; about transfer of copyright and related rights to third parties; the manufacturer's address for filing complaints.

Counterfeit CDs exhibit the lack of proper artistic design, manifested in the blurred images, misalignment of text relative to the central hole of the disc, chipped and uneven CD printing ink; discrepancy between the information provided on the CD label and in the inlay; grammar errors in the text; no names of rightsholder companies or their logos; no artist name and album title, album number under the rightsholder's catalogue.

Examining images on the audiovisual products' layout design items.

Comparative analysis of layout design between the counterfeit and legitimately manufactured products may indicate differences in a number of features.

1. Manufacturers use specific design for their legitimate products. Sometimes an entirely new design is developed for counterfeit products, using different or somewhat modified segments from the original products. If any discrepancy is identified in the design of a sample copy of the recorded audio product, a violation of the copyright to the layout design has taken place.

2. The following information is printed on the packaging: authors of audiovisual 
products; manufacturer; copyright mark (must comprise three components: the $\mathbb{C}$ copyright symbol itself, the name of the copyright holder and the date when the product was manufactured for the first time, or another protection mark for exclusive related rights "(T)", which also comprises three elements similar to those mentioned above); transfer of copyright and related rights to third parties; copyright holder; title and description of the audiovisual product; age restrictions; for erotic products - the information on a special expert examination; a brief overview of the product; details of the copyright holder (or seller) for filing complaints.

3. During the exclusive manufacture of audiovisual products, certain manufacturers use only a specific type of magnetic media whose playing time is usually different from a standard one (195 or 240 minutes). Only one film and a commercial are recorded on a videocassette.

4. Discrepancies in the design of the case, depending on the videocassette (either through the top or bottom side, or along the spine), as well as a different opening. There is no need to completely unglue the case - merely folding it will make the differences in the shape of the flaps quite obvious.

5. Using different translation for the same audiovisual product title.

6. Discolouration. Pink and red colours often tend to acquire a purple tint. This defect in graphics is particularly evident for the human eye.

7. Quality of printed images. Both vector (mostly small type and logos) and bitmap (for other images) graphics are used in the legitimately manufactured products. Cases for counterfeit products are printed using only bitmap graphics, which significantly affects the quality of smaller images. If a legitimately manufactured case was used as an original copy to print the case, superimposition of two bitmap graphics results in even more deteriorated image quality.

8. Using lower resolution bitmaps than for the original casing. This primarily affects the quality of smaller images, for example, frames from audiovisual products.

9. Fonts of other size and typeface are used. This may indicate that the images had been scanned and the texts had been retyped in a text editor.

10. Holographic stickers on the videocassette and/or its case. The hologram must contain the manufacturer's or the rightsholder's logo.

11. The use of finishing processes. In the printing industry, varnishing of the finished 
product is common. An additional section for applying varnish is often installed on printing equipment. The boundary of the varnish layer is sometimes clearly visible on the case flaps and can be detected by mechanical action: in the microscope, a transparent substance seems to appear on the surface - the so-called "dew point effect". Varnishing is intended to protect the cardboard case against soiling of the packaging. Colourless stamping with coloured tin foil is also used.

12. A sticker containing almost all the information listed in paragraph 1 must be attached to the videocassette case.

Whenever such expert examinations are performed, we generally have to handle a significant number of variously titled items of counterfeit audiovisual products. A comparison study, conducted in the manner adopted for forensic proceedings, along with a detailed description of variations from the sample copy, is quite a lengthy and time-consuming process. To make things easier, the above signs of counterfeit products are summarised in the table below [4].

Diagnostic and identification tasks are primarily addressed during the forensic analysis of chemicals (or their mixtures). To this end, a set of physical and chemical techniques for analysing their composition and production processes has been developed.

Regarding application of control stamps to copies of audiovisual works, phonograms, videograms, computer software, databases.

It should be noted that the Law "On Distribution of Copies of Audiovisual Works, Phonograms, Videograms, Computer Software, Databases" (the "Law on Control Stamps") is currently in force in Ukraine.

In practice, certain challenges, associated with the implementation of its provisions, emerged and, as a result, the control stamp mechanism has by now lost its relevance and efficiency. Shadow schemes of illegal purchase of control stamps, including through the use of bogus licence agreements, were becoming widespread. The "control stamp" protection element turned out to be faulty, allowing for initial markings to be tampered with by the perpetrators and for the counterfeit products to be stamped with such holographic elements.

The dynamics of control stamp purchases by bona fide manufacturers and distributors of copies of audiovisual works, phonograms, videograms, computer software, database 
indicate a significant decrease in the demand for this administrative service: from 14,000,000 control stamps in 2011 to $1,100,000$ in 2017.

In particular, national associations representing the interests of the music industry challenge further application of control stamps to phonogram copies [5].

A similar point of view has been voiced by international organisations for quite a long time. For example, in its 2010 Report, the International Intellectual Property Alliance (IIPA) noted that the existing hologram system in Ukraine is regarded by foreign experts as lacking transparency and should be substantially improved or repealed.

Conclusions The Ministry for Development of Economy, Trade and Agriculture of Ukraine registered with the Verkhovna Rada of Ukraine the draft Law of Ukraine "On Amendments to Certain Legislative Acts of Ukraine" (reg. No. 2565 of 10/12/2019), whereby the Law "On Distribution of Copies of Audiovisual Works, Phonograms, Videograms, Computer Software, Databases" is to be declared no longer in effect, while the relevant amendments and modifications are to be made to the Law of Ukraine "On Copyright and Related Rights", to the Criminal Code of Ukraine, the Criminal Procedure Code of Ukraine, and the Code of Ukraine on Administrative Offences.

\section{References}

1. Avdieieva H.K., 2006. Forensic examination of counterfeit audiovisual products (based on criminal case files). Monograph, ed. Professor V. Yu. Shepitko. Kharkiv: Pravo, available at http://dspace.nlu.edu.ua/bitstream/123456789/648/1/AvdeevaMono.pdf

2. The Law of Ukraine "On Distribution of Copies of Audiovisual Works, Phonograms, Videograms, Computer Software, Databases", available at https://zakon.rada.gov.ua/laws/show/1587-14

3. Lelotko Yu. I. The official web portal of the Verkhovna Rada of Ukraine. Available at http://elar.naiau.kiev.ua/jspui/bitstream/123456789/9057/1/\%D0\%A1\%D0\%A3\%D0\%94\%D 0\%9E\%D0\%92\%D0\%9E\%D0\%95\%D0\%9A\%D0\%A1\%D0\%9F\%D0\%95\%D0\%A0\%D0\%A2\%D0\%9D\%D0\%90_p 218-220.pdf

4. The Order No. 591 of the Ministry of Internal Affairs of Ukraine dated 17/07/2017. The official web portal of the Verkhovna Rada of Ukraine. Available at https://zakon.rada.gov.ua/laws/show/z1024-17 
5. The draft Law of Ukraine "On Amendments to Certain Legislative Acts of Ukraine", registration No. 2565 of 10/12/2019. The official web portal of the Verkhovna Rada of Ukraine. Available at http://w1.c1.rada.gov.ua/pls/zweb2/webproc4_1?pf3511=67591

6. Chvankin V.A. Osobennosti otdel'nykh kriminalisticheskikh issledovanii produktsii, obladaiushchei priznakami kontrafaktnosti : posob. [Features of individual forensic studies of products with signs of counterfeiting: handbook] / V.A. Chvankin, A.L. Poskreblo. - Minsk, 2005.

7. Chvankin V.A. Praktychni aspekty kryminalistychnyh doslidzhen' produkcii' $z$ oznakamy kontrafaktnosti : metod.rek. [ Practical aspects of forensic studies of products with signs of counterfeit: method.] / V.A. Chvankin, A.V. Kofanov. - K. : KYJ, 2008.

8. Chvankin V.A. Metodika tekhniko-kriminalisticheskogo issledovaniia poligraficheskogo oformleniia $i$ elementov zashchity magnitnykh $i$ opticheskikh nositelei informatsii, soderzhashchikh ob"ekty intellektual'noi sobstvennosti, v tseliakh ustanovleniia tekhnicheskikh priznakov kontrafaktnosti [Methodology of technical and forensic investigation of printing design and protection elements of magnetic and optical information carriers containing intellectual property objects, in order to establish technical signs of counterfeiting] / V.A. Chvankin // Kriminalisticheskoe obespechenie rassledovaniia i raskrytiia prestuplenii: nauch. tezisy, vystup. i soobshch, Kiev, 30 apr. 2010 g. / Kiev. nats. un-t vnutr. del Ukrainy. K.: KII, 2010. - S. 150-155.

\section{Translation of references to the original language}

6. Чванкин В.А. Особенности отдельных криминалистических исследований продукции, обладающей признаками контрафактности : пособ. / В.А. Чванкин, А.Л. Поскребло. - Минск, 2005.

7. Чванкін В.А. Практичні аспекти криміналістичних досліджень продукції 3 ознаками контрафактності : метод.рек. / В.А. Чванкін, А.В. Кофанов. - К. : КИЙ, 2008.

8. Чванкин В.А. Методика технико-криминалистического исследования полиграфического оформления и элементов защиты магнитных и оптических носителей информации, содержащих объекты интеллектуальной собственности, в целях установления технических признаков контрафактности / В.А. Чванкин // Криминалистическое обеспечение расследования и раскрытия преступлений: науч. тезисы, выступ. и сообщ, Киев, 30 апр. 2010 г. / Киев. нац. ун-т внутр. дел Украины. К.: КИЙ, 2010. - С. 150-155. 